\title{
KDM3A wt Allele
}

National Cancer Institute

\section{Source}

National Cancer Institute. KDM3A wt Allele. NCI Thesaurus. Code C134312.

Human KDM3A wild-type allele is located in the vicinity of $2 \mathrm{p} 11.2$ and is approximately 52 $\mathrm{kb}$ in length. This allele, which encodes lysine-specific demethylase $3 \mathrm{~A}$ protein, plays a role in the metabolism of histone $\mathrm{H} 3$. 